\title{
ANALSIS KEWENANGAN WAKIL BUPATI DALAM PENYELENGGARAAN PEMERINTAH DAERAH BERDASARKAN UNDANG-UNDANG NOMOR 9 TAHUN 2015 TENTANG PERUBAHAN UNDANG-UNDANG NOMOR 23 TAHUN 2014 TENTANG PEMERINTAH DAERAH
}

\author{
${ }^{1}$ Eva Lestari, ${ }^{2}$ Mukhlis, ${ }^{2}$ Yusrizal \\ Email: yusrizal@unimal.ac.id \\ ${ }^{1}$ Mahasiswa Fakultas Hukum Program Studi Hukum Unimal \\ ${ }^{2}$ Dosen Fakultas Hukum Program Studi Hukum Unimal
}

\begin{abstract}
ABSTRAK
Studi ini bertujuan umtuk menjelaskan tentang kewenangan dan hambatan Wakil Bupati dalam penyelenggaran pemerintah daerah yang berdasarkan UndangUndang Nomor 9 Tahun 2015 Tentang Perubahan Undang-Undang Nomor 23 Tahun 2014 Tentang Pemerintah Daerah. Kewenangan Wakil Bupati tidak diatur secara terperinci di dalam Undang-Undang Nomor 9 Tahun 2015 Tentang Perubahan Undang-Undang Nomor 23 Tahun 2014 Tentang Pemerintah Daerah sehingga menyebabkan adanya anggapan bahwa Wakil Bupati hanya simbol. Penelitian ini menggunakan jenis penelitian yuridis normatif dengan menggunakan pendekatan konseptual (conceptual approach), bersifat deskriptif dan bentuk penelitian preskriptif. Penelitian ini menggunakan bahan hukum premier berupa Undang-Undang Nomor 9 Tahun 2015 Tentang Perubahan Kedua Atas Undang-Undang Nomor 23 Tahun 2014 Tentang Pemerintah Daerah. Berdasarkan hasil analisis diketahui bahwa kewenangan Wakil Bupati dalam penyelenggaraan pemerinrah daerah yaitu membantu, memantau, mengoordinasikan, menindaklanjuti, melaksanakan mengupayakan, mengevaluasi, dan memberikan saran kepada Bupati. Melaksanakan tugas dan wewenang Bupati apabila Bupati menjalani masa tahanan atau berhalangan sementara. Melaksanakan tugas dan kewajiban pemerintahan lainnya yang diberikan oleh Bupati yang ditetapkan dengan keputusan Bupati, dan melaksanakan tugas bersama Bupati hingga akhir masa jabatan.. Hambatan Wakil Bupati dalam melaksanakan kewenangan berdasarkan Undang-Undang Nomor 9 Tahun 2015 Tentang Perubahan Kedua Atas Undang-Undang Nomor 23 Tahun 2014 Tentang Pemerintahan Daerah bahwa; lemahnya peraturan perundang-undangan mengenai hubungan kerja antara Bupati dan Wakil Bupati etika politik, kurangnya peranan Wakil Bupati, pertanggungjawaban Wakil Bupati kepada Bupati, dan ketidakharmonisan antara Bupati dengan Wakil Bupati.
\end{abstract}

Kata Kunci: Kewenangan, Wakil Bupati, Penyelenggaraan Pemerintah Daerah 


\section{PENDAHULUAN}

Istilah "kekuasaan" dan "wewenang" erat kaitannya dengan pelaksanaan fungsi pemerintahan. Menurut Kamus Hukum kata "wewenang” memiliki arti: (a) Hak dan kekuasaan bertindak; kewenangan; (b) Kekuasaan membuat keputusan memerintah dan melimpahkan tanggung jawab kepada orang lain; dan (c) Fungsi yang boleh atau tidak boleh dilaksanakan. Sedangkan "kewenangan" memiliki arti hak berwenang dan hak kekuasaan yang dipunyai oleh seseorang untuk melakukan sesuatu. ${ }^{1}$ Secara teoretis, kewenangan yang bersumber dari peraturan perundang-undangan diperoleh melalui 3 (tiga) cara yaitu atribusi, delegasi dan mandat. Khususnya, atribusi merupakan wewenang yang melekat pada suatu jabatan yang ada pada badan atau pejabat tata usaha negara yang dilawankan dengan wewenang yang dilimpahkan. ${ }^{2}$

Pengisian jabatan negara (staatsorganen, staatsambten) merupakan salah satu unsur penting dalam hukum tata Negara. Pengisian jabatan tidak hanya dilakukan sekali namun dilaksanakan secara reguler setiap periode tertentu untuk memilih pejabat pemimpin daerah guna menunjang berjalannya fungsi negara. Konsepsi Negara Kesatuan Republik Indonesia menerapkan desentralisasi, pengisian jabatan merupakan bentuk pengisian pejabat negara agar pelaksanaan fungsi pemerintahan daerah sebagai bagian dari pemerintahan pusat dapat terlaksana. ${ }^{3}$

Undang-Undang Nomor 9 Tahun 2015 Tentang Perubahan Kedua Atas Undang-Undang Nomor 23 Tahun 2014 Pemerintahan Daerah (UU Pemda) menyebutkan adanya perubahan susunan dan kewenangan pemerintahan daerah. Susunan pemerintahan daerah menurut undang-undang ini meliputi pemerintahan daerah provinsi, pemerintahan daerah kebupaten, dan DPRD. Pemerintahan daerah terdiri atas kepala daerah dan DPRD dibantu oleh perangkat daerah. Pemerintahan daerah provinsi terdiri atas pemerintah daerah provinsi dan DPRD provinsi. Aadapun pemerintah daerah kabupaten/kota terdiri atas pemerintah daerah kabupaten/kota dan DPRD kabupaten/kota.

Berdasarkan Pasal 66 UU Pemda mengatur secara jelas mengenai tugas dan fungsi Wakil Bupati. Tugas Wakil Bupati menurut UU Pemda yaitu: a) membantu Kepala Daerah memimpin pelaksanaan urusan pemerintahan yang menjadi kewenangan daerah, mengoordinasikan kegiatan perangkat daerah dan menindaklanjuti laporan dan/atau temuan hasil pengawasan aparat, memantau dan mengevaluasi penyelenggaraan pemerintahan daerah yang dilaksanakan oleh perangkat daerah provinsi bagi Wakil Gubernur, dan memantau dan mengevaluasi penyelenggaraan pemerintahan yang dilaksanakan oleh perangkat daerah

\footnotetext{
1 W.J.S. Purwodarminto, Kamus Umum Bahasa Indonesia, Balai Pustaka, Jakarta, 2006, hlm. 1150.

2 Yeyet Solihat dan Nanang Nugraha, Reposisi Kewenangan Wakil Kepala Daerah Dalam Penyelenggaraan Pemerintahan Daerah; Studi pada Pemerintahan Daerah Kabupaten Karawang, Jurnal Politikom Indonesiana, Vol. 1 No. 2, Desember 2016, hlm. 138.

${ }^{3}$ Sri Soemantri, Prosedur dan Sistem Perubahan Konstitusi. Alumni, Bandung, 2006, hlm. 174.
} 
kabupaten/kota, kelurahan, dan/atau Desa bagi wakil bupati/walikota; b) memberikan saran dan pertimbangan kepada kepala daerah dalam pelaksanaan pemerintahan daerah; c) melaksanakan tugas dan wewenang kepala daerah apabila kepala daerah menjalani masa tahanan atau berhalangan sementara; dan d) melaksanakan tugas lain sesuai dengan ketentuan peraturan perundangundangan.

Wakil Kepala Daerah juga memiliki tugas dan kewajiban pemerintahan lainnya yang diberikan Kepala Daerah melalui keputusan kepala daerah. Dalam melaksanakan tugas dan kewajibannya wakil kepala daerah mendandatangi pakta integritas. Selain itu, wakil kepala daerah dalam melaksanakan tugas dan kewajibannya bertanggung jawab kepada kepala daerah.

Berbagai tugas wakil kepala dearah berkaitan dengan kata kerja membantu, memantau, mengoordinasikan, menindaklanjuti, melaksanakan, mengupayakan, mengevaluasi, memberikan saran memerlukan kewenangan untuk melaksanakannya. Tanpa ada batas kewenagan delegasi yang jelas antara kepala daerah dan wakil kepala daerah berbagai tugas tersebut akan menjadi kabur dalam implementasi dan tanggungjawabnya. Kewenangan delegasi tersebut terutama berkaitan dengan aktivitas untuk memutuskan sesuatu, apabila keputusan yang telah diambil oleh wakil kepala daerah dimentahkan kembali oleh kepala daerah maka wibawa wakil kepala daerah akan pudar. ${ }^{4}$ Lemahnya keberadaan wakil kepala daerah dapat juga disebabkan perbedaan basis politik diantara keduanya, dan hal itu akan berdampak semakin memperbesarkan potensi konflik antara mereka yang menyebabkan pemerintah tidak efefektif. ${ }^{5}$

Persoalan ketidakjelasan kewenangan wakil kepala daerah menjadi sebuah persoalan manajemen pemerintahan dan hukum, tentu saja perlu memperoleh pengkajian lebih lanjut, dengan mengesampingkan dugaan politik dibelakang kasus-kasus terjadi, disharmonisasi kepala daerah perlu dikembalikan perkaitannya dengan menunjuk pada isi materi atau materi muatan dalam ketentuan peraturan perundangan. Bahwa perselisihan kewenangan merupakan peristiwa manajemen pemerintahan dan hukum yang dipandang tidak akan terjadi apabila Bupati dan Wakil Bupati memahami betul manajemen pemerintahan serta teks-teks yuridis yang tersedia dalam hal ini Undang-Undang Nomor 9 Tahun 2015 Tentang Perubahan Kedua Atas Undang-Undang Nomor 23 Tahun 2014 Tentang Pemerintahan Daerah, telah memberikan batasan yang tegas dalam hal wewenang, kedudukan, kewajiban, tugas dan fungsi antara Bupati dan Wakil Bupati. ${ }^{6}$

Perselisihan kewenangan atribusi antara Bupati dengan Wakil Bupati telah

\footnotetext{
${ }^{4}$ Sri Soemantri, Op. Cit., hlm. 4.

5 Suharizal, Pemilihan Kepala Daerah: Regulasi, Dinamika dan Konsep Mendatang, Raja Grafindo Persada, Jakarta, 2011, hlm. 215.

6 Yeyet Solihat dan Nanang Nugraha, Reposisi Kewenangan Wakil Kepala Daerah Dalam Penyelenggaraan Pemerintahan Daerah; Studi pada Pemerintahan Daerah Kabupaten Karawang, Jurnal Politikom Indonesiana, Vol. 1 No. 2, Desember 2016, hlm. 136.
} 
menjadi persoalan yang menghambat kinerja pelaksanaan otonomi, sampai pada masalah bahwa Wakil Bupati pada faktanya merupakan wakil dan konstituen yang terus menerus menyampaikan dan mempertanyakan aspirasinya, kesemuanya merupakan contoh-contoh kasus yang bukan saja hanya dapat dilihat pada sisi dampak yang dalam prakteknya mempengaruhi kineija birokrasi, tetapi lebih dan itu perlu dimengerti merupakan sebuah persoalan dan akibat tidak jelasnya manajemen pemerintahan dan hukum atas kewenangan, kedudukan, tugas dan fungsi Wakil Bupati. ${ }^{7}$

Kewenangan atribusi Bupati dan Wakil Bupati terletak pada pemahaman pada manajemen pemerintahan serta ketidakjelasan tugas dan wewenang atribusi Wakil Bupati. Ketentuan Pasal 66 ayat (1) Undang-Undang Nomor 23 Tahun 2014 Tentang Pemerintah Daerah menjadi kunci mengingat tugas-tugas di ayat lainnya yang cenderung formalis, normatif dan sulit ditentukan batasannya. Sementara, ketentuan yang menyatakan bahwa Wakil Bupati memiliki tugas dan wewenang atribusi untuk melaksanakan tugas dan kewajiban pemerintahan lainnya yang diberikan oleh Bupati ini, sebetulnya cenderung implementatif. Tinggal kemudian bagaimana merumuskan pemberian tugas oleh Bupati dimaksud ke dalam sebuah fakta yang dapat menjadi perikatan dan landasan proses. $^{8}$

Berdasarkan uraian di atas, penulis tertarik untuk meneliti tentang "Analisis Kewenangan Wakil Bupati Dalam Penyelenggaraan Pemerintah Daerah Berdasarkan Undang-Undang Nomor 9 Tahun 2015 Tentang Perubahan Kedua Atas Undang-Undang Nomor 23 Tahun 2014 Tentang Pemerintahan Daerah".

\section{METODE PENELITIAN}

Studi ini menggunakan jenis penelitian yuridis normatif, yaitu penelitian yang difokuskan untuk mengkaji penerapan kaidah-kaidah atau norma-norma dalam hukum positif. ${ }^{9}$ Jenis penelitian hukum yang digunakan dalam penelitian ini adalah penelitian hukum normatif, yaitu penelitian berdasarkan bahan-bahan hukum yang fokusnya pada membaca dan mempelajari bahan-bahan hukum primer dan sekunder. ${ }^{10}$ Dalam penelitian ini bahan hukum yang dimaksud mengenai kewenangan Wakil Bupati dalam penyelenggaraan pemerintah daerah berdasarkan Undang-Undang Nomor 9 Tahun 2015 Tentang Perubahan Kedua Atas Undang-Undang Nomor 23 Tahun 2014 Tentang Pemerintahan Daerah.

Penelitian ini menggunakan pendekatan perundang-undangan (statute aproach) dan pendekatan kasus (case aproach). Pendekatan perundang- undangan digunakan untuk mengetahui keseluruhan peraturan hukum khususnya hukum

\footnotetext{
7 Indroharto, Usaha Memahami Undang-Undang tentang Peradilan Tata Usaha Negara, Sinar Harapan, Jakarta, 2003. hlm. 136.

8 Ibid., hlm. 137.

9 Johny Ibrahim, Teori, metode dan penelitian hukum normatif, Bayumedia publishing, Malang, 2006. Hlm. 29.

10 Ibid., hlm. 57.
} 
ketatanegaraan di Indonesia. Penelitian ini bersifat deskriptif, yaitu sebuah penelitian yang bertujuan untuk memggambarkan secara tepat sifat-sifat suatu individu, gejala atau penyebaran suatu gejala atau frekuensi adanya hubungan tertentu antara suatu gejala dengan gejala yang lain dalam masyarakat. ${ }^{11}$ Yakni mengenai kewenangan Wakil Bupati dalam penyelenggaraan pemerintah daerah berdasarkan Undang-Undang Nomor 9 Tahun 2015 Tentang Pemerintahan Daerah.

\section{PEMBAHASAN}

\section{Kewenangan Wakil Bupati Dalam Penyelenggaraan Pemerintah Daerah Berdasarkan Undang-Undang Nomor 9 Tahun 2015 Tentang Perubahan Kedua Atas Undang-Undang Nomor 23 Tahun 2014 Tentang Pemda}

Menurut Indarto, dalam penyelenggaraan pemerintahan dalam suatu negara hukum baik di tingkat pusat maupun di tingkat daerah haruslah berdasarkan pada cara legalitas, yaitu cara yang mencanangkan bahwa tanpa dasar wewenang yang diberikan oleh suatu peraturan perundang-undangan yang berlaku, maka segala macam aparat pemeritah itu tidak memiliki wewenang yang dapat mempengaruhi atau mengubah keadaan atau posisi warga masyarakatnya. ${ }^{12}$ Kewenangan harus dilandasi oleh ketentuan hukum yang ada (konstitusi), sehingga kewenangan tersebut merupakan kewenangan yang sah. Dengan demikian, pejabat (organ) dalam mengeluarkan keputusan didukung oleh sumber kewenangan tersebut.

Secara konseptual, istilah wewenang atau kewenangan sering disejajarkan dengan istilah Belanda "bevoegdheid" (yang berarti wewenang atau berkuasa). Menurut kamus besar bahasa indonesia, kata wewenang disamakan dengan kata kewenangan, yang diartikan sebagai hak dan kekuasaan untuk bertindak, kekuasaan membuat keputusan, memerintah dan melimpahkan tanggung jawab kepada orang/badan lain.13 Penjelasan tentang konsep wewenang, dapat juga didekati melalui telaah sumber wewenang dan konsep pembenaran tindakan kekuasaan pemerintahan. Sumber wewenang tersebut meliputi atribusi, delegasi, dan mandat. ${ }^{14}$

Atribusi adalah pemberian wewenang pemerintahan oleh pembuat undangundang kepada organ pemerintahan. Atribusi terjadi karena pemberian wewenang pemerintahan yang baru oleh suatu ketentuan dalam peraturan perundang-undangan. ${ }^{15}$ Delegasi adalah pelimpahan wewenang pemerintahan dari satu organ kepada organ pemerintahan lainnya. Dalam membicarakan delegasi dalam hal ada pemindahan atau pengalihan suatu kewenangan yang ada bila kewenangan itu kurang sempurna, maka keputusan yang berdasarkan kewenangan itu tidak sah menurut hukum. Kewenangan delegasi dalam membuat keputusan harus didasarkan pada suatu undang-undang

\footnotetext{
${ }^{11}$ Fakultas Hukum Universitas Malikussaleh, Buku Panduan Akademik, Unimal Press, Lhokseumawe, 2015, hlm. 111-112.

12 Indroharto, Usaha Memahami Undang-Undang Tentang Peradilan Tata Usaha Negara, Pustaka Sinar Harapan, Jakarta, 2003, hlm. 83.

13 Kamal Hidjaz, Efektivitas Penyelenggaraan Kewenangan Dalam Sistem Pemerintahan DaerahDi Indonesia, Pustaka Refleksi, Makasar, 2010, hlm. 35.

14 SF. Marbun, Peradilan Administrasi Negara dan Upaya Administrasi di Indonesia, Liberty, Yogyakarta, 2002. hlm 172.

15 Yeyet Solihat dan Nanang Nugraha, Op.Cit.,, hlm. 136.
} 
formal. ${ }^{16}$ Sedangkan mandat adalah kekuasaan untuk melakukan kewenangan kekuasaan dari suatu badan atau organ kekuasaan atas nama badan atau organ kekuasaan tersebut. Mandat terjadi ketika organ pemerintahan mengizinkan kewenangannya dijalankan oleh organ lain atas namanya.

Secara yuridis, ketentuan mengenai Kepala Daerah dan Wakil Kepala Daerah diatur dalam konstutusi yaitu dalam ketentuan Pasal 18 ayat (4) Undang Undang Dasar 1945 menyatakan bahwa Gubernur, Bupati dan Walikota masing-masing sebagai kepala pemerintahan daerah provinsi, kabupaten dan kota dipilih secara demokratis.

Bupati sebagai pemimpin daerah tingkat Kabupaten memiliki kewenangan dalam penyelenggaraan pemerintah daerah yang dibantu oleh Wakil Bupati. Walaupun Dalam Undang-Undang Pemilu, Bupati dan Wakil Bupati merupakan satu paket, secara kewenangan terdapat perbedaan dalam pengambilan keputusan, hal itu termaktub dalam Pasal 65 dan Pasal 66 Undang-Undang Nomor 9 Tahun 2015 tentang Perubahan Kedua Atas Undang-Undang Nomor 23 Tahun 2014 tentang Pemerintahan Daerah (UU Pemda).

Dalam teori efektifitas hukum. Menurut Van Loan mangatakan bahwa efektivitas suatu perundang-undangan berarti bahwa tujuannya tercapai. Hal ini menunjukkan bahwa suatu undang-undang nanti bisa disebut berjalan efektif jika tujuan pembentukannya tercapai. ${ }^{17}$ Tujuan dari ketentuan Pasal 66 Undang-Undang Pemda adalah agar Bupati dan wakilnya ada kerjasama agar pekerjaan bisa lebih mudah dan tidak lagi terhambat dari kepentingan politik jangka pendek tetapi lebih berorientasi pada upaya membangun sistem hukum yang lebih kuat dan berlakunya efektif.

Kewenangan Bupati dan Wakil Bupati sudah dibatasi oleh undang-undang sehingga Bupati dan Wakil Bupati memiliki tugas dan tanggung jawab masing-masing dalam penyelenggaraan Pemerintahan Daerah. Wakil Bupati dapat berwenang sebagaimana wewenang Bupati dengan ketentuan apabila Bupati "sedang menjalani masa tahanan" atau "berhalangan sementara", karena dalam hal Bupati sedang menjalani masa tahanan dilarang melaksanakan tugas dan kewenangannya sebagaimana disebutkan dalam Pasal 65 ayat 4 Undang-Undang Pemda bahwa "Dalam hal kepala daerah sedang menjalani masa tahanan sebagaimana dimaksud pada ayat (3) atau berhalangan sementara, wakil kepala daerah melaksanakan tugas dan wewenang kepala daerah". ${ }^{18}$

Selain sedang menjalani masa tahanan dan berhalangan sementara juga Wakil Bupati dapat melaksanakan tugas yang diberikan Bupati dengan mengeluarkan penetapan mengenai pelimpahan wewenang melalui keputusan Bupati. Hal ini dimungkinkan oleh undang-undang mengingat beban dan tanggung jawab Bupati yang dirasa terlalu besar sehingga Bupati diberikan hak untuk melimpahkan pelaksanaan tugas dan kewajiban pemerintahan lainnya kepada Wakil Bupati.

Dalam melaksanakan tugasnya, Wakil Bupati bertanggung jawab kepada Bupati "prinsip subordinasi". Rincian tugas bagi Wakil Bupati tidak disertai rincian kewenangan yang diperlukan untuk menjalankan tugas tersebut, inilah kelemahan terhadap UndangUndang Nomor 9 Tahun 2015 Tentang Perubahan Kedua Atas Undang-Undang Nomor

16 Ibid.

17 Soerjono Soekanto, Pengantar Penelitian Hukum, Universitas Indonesia Press, Jakarta, 2002, hlm. 85.

18 Republik Indonesia, Undang-Undang Nomor 9 Tahun 2015 Tentang Perubahan Kedua Atas Undang-Undang Nomor 23 Tahun 2014 Tentang Pemerintahan Daerah, Pasal 65 Ayat 4. 
23 Tahun 2014 Tentang Pemerintahan Daerah, di mana masih ada rincian tugas dan kewenangan Wakil Bupati yang tidak diatur.

Berbagai tugas Wakil Bupati berkaitan dengan kata kerja seperti, membantu, memantau, mengoordinasikan, menindaklanjuti, melaksanakan, mengupayakan, mengevaluasi, memberikan saran memerlukan kewenangan untuk melaksanakannya, jika kewenangan itu sendiri tidak diberikan atau tidak di atur, maka Wakil Bupati akan sulit untuk melakukan pekerjaan-pekerjaan tersebut. Tanpa ada batas kewenangan yang jelas antara Bupati dengan Wakil Bupati, berbagai tugas tersebut akan menjadi kabur dalam implementasi dan tanggung jawabnya, kewenangan tersebut terutama berkaitan dengan aktivitas untuk memutuskan sesuatu, apabila keputusan yang telah diambil oleh Wakil Bupati dimentahkan kembali oleh Bupati, maka wibawa dan rasa percaya Wakil Bupati akan pudar. Lemahnya keberadaan wakil kepala daerah dapat juga disebabkan perbedaan basis politik diantara keduanya, dan hal itu akan berdampak semakin memperbesarkan potensi konflik antara mereka yang menyebabkan pemerintah tidak efefektif. ${ }^{19}$

Kewenangan yang dimiliki Wakil Bupati dalam Undang-Undang Nomor 9 Tahun 2015 Tentang Perubahan Kedua Atas Undang-Undang Nomor 23 Tahun 2014 Tentang Pemerintahan Daerah ialah kewenangan hasil dari pemberian Bupati atau bisa juga dikatakan mandat, sejauh ini kewenangan Wakil Bupati lahir dengan dua cara, yaitu jika Bupati memberikan sebuah kewenangan kepada Wakil Bupati bisa dengan berupa Peraturan Daerah atau dengan surat keputusan Bupati, dan jika Bupati berhalangan, maka posisi Bupati sebagai tampuk pimpinan tertinggi, kewenangan dan tugas yang dimiliki Bupati beralih ke Wakil Bupati.

Mengenai kedudukan Wakil Bupati, maka kita akan dihadapkan kepada kewenangan dan peran dari Bupati dalam menjalankan tugas yang diembannya. Walaupun jabatan Wakil Bupati masih dianggap jabatan inkonstitusional karena tidak disebutkan secara eksplisit di dalam UUD 1945, namun dalam perkembangannya kewenangan dan peran Wakil Bupati ini sudah diatur di dalam Undang-Undang Nomor 9 Tahun 2015 Tentang Perubahan Kedua Atas Undang-Undang Nomor 23 Tahun 2014 Tentang Pemerintahan Daerah, dimana undang-undang tentang pemerintahan daerah ini selama pasca reformasi telah terjadi beberapa kali revisi dan perubahan. Akan tetapi apakah Undang-Undang tentang Pemerintahan Daerah ini telah mengatur dengan jelas dan terperinci untuk hal kewenangan Wakil Bupati, karena landasan Hukum seperti Undang-Undang akan sangat menentukan nantinya dari kedudukan dan tugas dari Wakil Bupati yang akan berimbas pada kedudukan Wakil Bupati di dalam Pemerintahan Daerah.

\section{Hambatan Wakil Bupati Dalam Melaksanakan Kewenangan Berdasarkan Undang- Undang Nomor 9 Tahun 2015 Tentang Perubahan Kedua Atas Undang-Undang Nomor 23 Tahun 2014 Tentang Pemda}

19 Suharizal, Pemilihan Kepala Daerah: Regulasi, Dinamika dan Konsep Mendatang, Raja Grafindo Persada, Jakarta, 2011, hlm. 215. 
Wakil Kepala Daerah atau Wakil Bupati selama ini sering dipertanyakan peran dan fungsinya, ini tidak lepas dari banyaknya kritikan terhadap kinerja Wakil Bupati, serta banyaknya disharmonis antara Bupati dan Wakil Bupati dalam menjalankan pemerintahan daerah. Wakil Bupati merupakan pejabat dalam struktur pemerintahan daerah, namun keberadaannya sampai saat ini masih menjadi polemik dengan asumsi bahwa jabatan Wakil Bupati merupakan jabatan inkonstitusional karena tidak disebutkan secara eksplisit dalam UUD NRI 1945. Dalam Pasal 18 Ayat (4) menyatakan Gubernur, Bupati, dan Walikota masing-masing sebagai kepala pemerintah daerah provinsi, kabupaten, dan kota dipilih secara demokratis. Dari bunyi Pasal 18 UUD ini dapat kita lihat tidak ada sama sekali menyebutkan tentang keberadaan dari wakil kepala daerah (Wakil Bupati). jika dilihat dari isi pasal 18 ayat 4 UUD 1945 ini, maka wakil kepala daerah tidak dikenal karena isi pasal ini hanya menyebutkan Kepala Daerah. Kedudukan Wakil Bupati sering dianggap hanya sebagai pelengkap dari struktural pemerintahan daerah saja, dimana kedudukan Wakil Bupati ini tidak terlalu diperhitungkan seriring kurangnya tugas dan kewenangan dalam peran yang diberikan kepada Wakil Bupati, dan ini sangat berdampak pada hubungan yang tidak harmonis antara Bupat dan Wakil Bupati.

Secara yuridis bahwa wewenang Wakil Bupati dapat dikategorikan sebagai berikut:20

a. Kewenangan Mutlak, yaitu kewenangan Wakil kepala daerah yang diperoleh dari peraturan perundang-undangan. Pasal 66 Undang-Undang Nomor 9 Tahun 2015 Tentang Perubahan Kedua Atas Undang-Undang Nomor 23 Tahun 2014 tentang Pemerintahan Daerah menyatakan bahwa Wakil kepala daerah bertugas memantau dan mengevaluasi penyelenggaraan pemerintahan di wilayah kecamatan, kelurahan dan/atau desa bagi Wakil kepala daerah kabupaten/kota.

b. Kewenangan Pemberian, yaitu kewenangan Wakil kepala daerah untuk menjalankan roda pemerintahan yang diperolehnya berdasarkan rekomendasi kepala daerah. Wakil kepala daerah bertugas melaksanakan tugas dan kewajiban pemerintahan lainnya yang diberikan oleh kepala daerah.

c. Kewenangan otomatis, yaitu kewenangan Wakil kepala daerah yang diperoleh secara otomatis, jika kepala daerah tidak berada di tempat, atau tidak dapat melaksanakan kewajiannya sebagai Wakil kepala daerah.

d. Wakil kepala daerah menggantikan kepala daerah sampai habis masa jabatannya apabila kepala daerah meninggal dunia, berhenti, diberhentikan, atau tidak dapat melakukan kewajibannya selama 6 (enam) bulan secara terus menerus dalam masa jabatannya.

Tugas jabatan Wakil Bupati, tidak ada yang secara khusus diberikan oleh UndangUndang Nomor 9 Tahun 2015 Tentang Perubahan Kedua Atas Undang-Undang Nomor 23 Tahun 2014 tentang Pemerintahan Daerah, sehingga lebih cenderung pada kemauan pribadi Bupati apakah mau berbagi tugas dengan wakilnya. Sedangkan, untuk berjalannya pemerintahan secara efektif dan efesien diperlukan adanya pembagian tugas antara Bupati dan Wakil Bupati, mengingat dalam praktek penyelenggaraan pemerintahan meliputi banyak urusan yang telah dilimpahkan oleh Pemerintah Pusat kepada Pemerintah Daerah, baik Urusan Wajib maupun Urusan Pilihan.

${ }^{20}$ Ibid., hlm. 196. 
Tugas Bupati dan Wakil Bupati sangat luas dan meliputi banyak sektor dan bidang, sehingga jika yang bekerja hanya Bupati seorang diri yang memikirkan dan mengendalikan berbagai banyak tugas itu dipastikan pemerintahan tidak akan berjalan efektif. Untuk itu pembuat Undang-Undang Nomor 9 Tahun 2015 Tentang Perubahan Kedua Atas Undang-Undang Nomor 23 Tahun 2014 tentang Pemerintahan Daerah khususnya pada ketentuan pada Pasal 66, merupakan suatu pemikiran yang jauh ke depan karena sudah memikirkan bahwa penyelenggaraan pemerintahan daerah membutuhkan kepemimpinan yang solid antara Bupati dan Wakil Bupati, apalagi Bupati dan Wakil Bupati sebagai pimpinan daerah dipilih secara paket melalui pemilihan langsung. Oleh karena itu dengan tidak tegasnya tugas jabatan Bupati dan Wakil Bupati dalam ketentuan Pasal 66 pada Undang-Undang Nomor 9 Tahun 2015 Tentang Perubahan Kedua Atas Undang-Undang Nomor 23 Tahun 2014 tentang Pemerintahan Daerah, akan berpotensi menimbulkan gesekan kepentingan diantara keduanya dan akan berimplikasi pada tidak efektifnya baik koordinasi antara Bupati dan Wakil Bupati maupun keduanya kepada para pejabat perangkat daerah. Dengan demikian terdapat hambatan Wakil Bupati dalam melaksanakan kewenangannya baik secara yuridis normatif dan dalam hubungannya dengan Bupati.

Berdasarkan uraian-uraian di atas, penulis dapat menganalisa bahwa hambatan Wakil Bupati dalam melaksanakan kewenangan menurut yuridis normatif antara lain: (a) Lemahnya peraturan perundang-undangan mengenai hubungan kerja antara keduanya dan diabaikannnya etika politik; (b) Ketidakjelasan kewenangan atau kurangnya peranan Wakil Bupati yang menyebabkan posisi Wakil Bupati hanya sebagai 'ban serep' atau 'pemain cadangan' saja; (c) Ketentuan Undang-Undang Nomor 9 Tahun 2015 Tentang Perubahan Kedua Atas Undang-Undang Nomor 23 Tahun 2014 tentang Pemerintahan Daerah yang mengatur pertanggungjawaban Wakil Bupati kepada Bupati, menjadikan kedudukan keuangan dan protokoler Wakil Bupati tidak fair.

Hambatan Wakil Bupati dalam melaksanakan kewenangan dalam hubungannya dengan Bupati ternyata kini banyak ditemukan terjadinya ketidakharmonisan antara Bupati dengan Wakil Bupati. Selain itu, hambatan Wakil Bupati dalam melaksanakan kewenangannya yang diberikan oleh Bupati tidak memiliki batasan yang jelas meskipun dalam Undang-Undang Nomor 9 Tahun 2015 Tentang Perubahan Kedua Atas UndangUndang Nomor 23 Tahun 2014 tentang Pemerintahan Daerah, semua sudah diatur, apa tugas seorang Bupati dan Wakil Bupati. Permasalahan apa yang akan dilakukan oleh Wakil Bupati juga tergantung pada delegasi dari Bupati. Tugas yang didapatkan oleh Wakil Bupati ditentukan oleh kepala daerah, sehingga Wakil Bupati disini terkesan hanya sebagai tenaga pembantu yang menunggu perintah, tanpa bisa berbuat sesuatu jika kepala daerah melakukan kesalahan atau semacamnya.

\section{KESIMPULAN}

Berdasarkan hasil penelitian dan pembahasan, maka dapat disimpulkan bahwa; kewenangan Wakil Bupati dalam penyelenggaraan pemerintah daerah berdasarkan Undang-Undang Nomor 9 Tahun 2015 Tentang Perubahan Kedua Atas Undang-Undang Nomor 23 Tahun 2014 Tentang Pemerintahan Daerah yaitu Wakil Bupati yaitu membantu, memantau, mengoordinasikan, menindaklanjuti, melaksanakan, mengupayakan, mengevaluasi, dan memberikan saran kepada Bupati. Melaksanakan tugas dan wewenang Bupati apabila Bupati menjalani masa tahanan atau berhalangan 
sementara. Melaksanakan tugas dan kewajiban pemerintahan lainnya yang diberikan oleh Bupati yang ditetapkan dengan keputusan Bupati, dan melaksanakan tugas bersama Bupati hingga akhir masa jabatan. Hambatan Wakil Bupati dalam melaksanakan kewenangan berdasarkan Undang-Undang Nomor 9 Tahun 2015 Tentang Perubahan Kedua Atas Undang-Undang Nomor 23 Tahun 2014 Tentang Pemerintahan Daerah yaitu (a) Lemahnya peraturan perundang-undangan mengenai hubungan kerja antara keduanya dan diabaikannnya etika politik; (b) Ketidakjelasan kewenangan atau kurangnya peranan Wakil Bupati yang menyebabkan posisi Wakil Bupati hanya sebagai pengganti pada saat Bupati berhalangan atau pada saat Bupati melakukan perjalanan dinas keluar daerah; (c) Ketentuan Undang-Undang Nomor 9 Tahun 2015 Tentang Perubahan Kedua Atas Undang-Undang Nomor 23 Tahun 2014 tentang Pemerintahan Daerah yang mengatur pertanggungjawaban Wakil Bupati kepada Bupati, menjadikan kedudukan keuangan dan protokoler Wakil Bupati tidak fair; dan (d) ketidakharmonisan antara Bupati dengan Wakil Bupati karena Wakil Bupati tidak memiliki peran dan kewenangan yang besar. Tugas Wakil Bupati adalah membantu Bupati. Jika Bupati membagi sebagian kewenangannya, Wakil Bupati bisa mendapat bagian fungsi atau kewenangan. Tapi jika tidak, peran Wakil Bupati sangat terbatas. Kecuali disaat Bupati berhalangan menjalankan fungsinya.

\section{DAFTAR PUSTAKA}

Fakultas Hukum Universitas Malikussaleh. 2015. Buku Panduan Akademik. Lhokseumawe: Unimal Press.

Indroharto. 2003. Usaha Memahami Undang-Undang Tentang Peradilan Tata Usaha Negara. Jakarta: Sinar Harapan.

Johny Ibrahim. 2006. Teori, Metode dan Penelitian Hukum Normatif. Malang: Bayumedia Publishing.

Kamal Hidjaz. 2010. Efektivitas Penyelenggaraan Kewenangan Dalam Sistem Pemerintahan Daerah di Indonesia. Yogyakarta: Pustaka Refleksi.

S.F Marbun. 2002. Peradilan Administrasi Negara dan Upaya Administrasi di Indonesia. Yogyakarta: Liberty.

Soerjono Soekanto. 2002. Pengantar Penelitian Hukum. Jakarta: Universitas Indonesia Press.

Sri Soemantri. 2006. Prosedur dan Sistem Perubahan Konstitusi. Bandung: Alumni.

Suharizal. 2011. Pemilihan Kepala Daerah: Regulasi, Dinamika dan Konsep Mendatang. Jakarta: Raja Grafindo Persada.

Yeyet Solihat dan Nanang Nugraha. 2016. Reposisi Kewenangan Wakil Kepala Daerah Dalam Penyelenggaraan Pemerintahan Daerah; Studi pada Pemerintahan Daerah Kabupaten Karawang. Jurnal Politikom Indonesiana, Vol. 1 No. 2, hlm. 136.

W.J.S. Purwodarminto. 2006. Kamus Umum Bahasa Indonesia. Jakarta: Balai Pustaka. Undang-Undang Nomor 9 Tahun 2015 Tentang Perubahan Kedua Atas Undang-Undang Nomor 23 Tahun 2014 Tentang Pemerintahan Daerah. 